\title{
A Comparative Study of Sewerage Treatment Plants With Different Technologies In The Vicinity Of Chandigarh City
}

\author{
Prerna Sharma, Dr. R.K Khitoliya, Dr. S.Kumar \\ Department of Civil Engineering, Environmental Engineering, Punjab Engineering college (PEC) Chandigarh \\ $-160012,2013$
}

\begin{abstract}
Chandigarh city has a well planned underground network of pipes for the disposal of sewerage generated in the city. The sewerage system of the city has been designed by taking into account the natural slope of the city, which is from north to south. Chandigarh city hosts three Sewerage Treatment Plants (STP's) namely: STP "Diggian" located at sector 66 of S.A.S Nagar, Punjab Territory, Mohali, based upon MBBR (Moving Bed Biofilm Reactor) technology which is at a distance of about $4 \mathrm{~km}$ from the nearest planned sector 47, STP Raipur Kalan located at a distance of $6 \mathrm{~km}$ from Chandigarh adjoining to railway station based upon UASB (Upflow Anaerobic Sludge Blanket) technology and STP Raipur Khurd, based upon ASP (Activated Sludge Process) technology located on Chandigarh-Ambala highway at a distance of approximately $8 \mathrm{~km}$ from Interstate Bus Terminal sector 17, $1 \mathrm{~km}$ from Airport and $3 \mathrm{~km}$ from Railway Station. These plants are designed and constructed with an aim to manage waste water so as to minimize or remove organic matter, solids and other pollutants before it enters a water body.

In the present study various Physico-Chemical and Biological Parameters are evaluated and are compared with the Central Pollution Control Board (CPCB) General Standards for the Discharge of Environmental Pollutants Part-A : Effluents, into Inland Surface Water according to The Environment (Protection) Rules, 1986 Schedule-VI because the Effluent from these STP's enters river Ghaggar. Also the performance of each STP was evaluated in terms of Removal/Reduction Efficiency. Since out of 30 MGD of STP, Mohali 10 MGD treated waste water is reused for Irrigation purpose in various gardens and lawns of Sector : 19, 20, 21, 29, 30, 33, 34, 36, 40, 42, 43, 44, 46, 47, 48, 51 and 52 of Chandigarh city therefore Average Effluent of this STP is compared with the CPCB Effluent Discharge Standards into Land for Irrigation.

It was observed according to the results obtained that BOD value of the Effluent of STP Raipur Kalan and Raipur Khurd was not under permissible limit during the duration of study and Average Phosphate value of Raipur Khurd was exactly upto permissible limit according to Central Pollution Control Board (CPCB) General Standards for the Discharge of Environmental Pollutants Part-A: Effluents, into Inland Surface Water according to The Environment (Protection) Rules, 1986 Schedule-VI.

According to the results obtained it was also revealed that all the Physico-Chemical and Biological Parameters evaluated for STP Mohali was under permissible limit according to CPCB Effluent Discharge Standards into Land for Irrigation and also into Inland Surface water.

Also it was revealed from the performance study that efficiency of the three STP's mentioned above was poor with respect to removal of TDS (Total Dissolved Solids) in contrast to the removal /reduction efficiency in other parameters like TSS (Total Suspended Solids), BOD (Biochemical Oxygen Demand) and COD (Chemical Oxygen Demand). The order of reduction efficiency was 1.TDS(39\%) 2.COD(56\%) 3.TSS(76\%) 4.BOD(79\%), 1.TDS(46\%) $2 . T S S(51 \%) \quad 3 . B O D(73 \%) \quad 4 . C O D(78 \%)$ and $1 . T D S(55 \%)$ 2.COD(75\%) 3.TSS(78\%) 4.BOD(88\%) respectively in Raipur Kalan STP, Raipur Khurd STP and "Diggian" Mohali STP. In comparison with each other, out of the three STP's, "Diggian" STP Located at Mohali showed better results for the effluent, its reduction efficiency for BOD is $88 \%$ and is highest among Raipur Kalan STP and Raipur Khurd STP which is 79\% and 73\% respectively. From the evaluation it is further revealed that Mohali STP based upon MBBR technology have more stable results than Raipur Kalan STP, based upon UASB technology and Raipur Khurd STP, based upon ASP technology. The order of overall performance for the technologies studied in different STP's are: 1.MBBR 2.UASB 3.ASP which proves that $M B B R$ technology is ahead to UASB and ASP technology in the treatment of sewage.

Additionally, the working principle, problems associated with the operation and maintenance of all the three STP's is also discussed.
\end{abstract}

\section{Introduction}

30 MGD SEWERAGE TREATMENT PLANT, "DIGGIAN" BASED UPON MBBR TECHNOLOGY, AT SECTOR 66 S.A.S NAGAR, PHASE 11, MOHALI 
The sewage received at this STP is subjected to primary, secondary and tertiary treatment. 30 MGD is treated upto tertiary level and out of $30 \mathrm{MGD}, 10 \mathrm{MGD}$ treated waste water or sewage is recycled back to the city for irrigation of open spaces/ gardens. The 20 MGD treated sewage is disposed off in an open Nallah and finally it meets river Ghaghar..

\section{MGD SEWERAGE TRATMENT PLANT BASED UPON UASB TECHNOLOGY RAIPUR}

KALAN, CHANDIGARH

STP Raipur Kalan is located at a distance of $6 \mathrm{~km}$ from Chandigarh adjoining to railway station and is based upon UASB (Upflow Anaerobic Sludge Blanket) technology.

\subsection{MGD SEWERAGE TREATMENT PLANT BASED UPON ASP TECHNOLOGY AT RAIPUR KHURD, CHANDIGARH}

STP Raipur Khurd, based upon ASP (Activated Sludge Process) technology is located on Chandigarh-Ambala highway at a distance of approximately $8 \mathrm{~km}$ from Interstate Bus Terminal sector 17, $1 \mathrm{~km}$ from Airport and 3 $\mathrm{km}$ from Railway Station, Chandigarh.

COMPARISON BETWEEN RAIPUR KALAN, RAIPUR KHURD AND MOHALI STP

\begin{tabular}{|c|c|c|c|c|}
\hline $\begin{array}{l}\text { SR.N } \\
\text { O }\end{array}$ & PARAMETERS & $\begin{array}{c}\text { RAIPUR KALAN } \\
\text { STP } \\
\text { (UASB } \\
\text { TECHNOLOGY) } \\
\end{array}$ & $\begin{array}{c}\text { RAIPUR KHURD } \\
\text { STP } \\
\text { (ASP } \\
\text { TECHNOLOGY) } \\
\end{array}$ & $\begin{array}{c}\text { MOHALI STP } \\
\text { (FAB/MBBR } \\
\text { TECHNOLOGY) }\end{array}$ \\
\hline 1. & Type of process & Anaerobic & Aerobic & $\begin{array}{l}\text { Aerobic, Attached } \\
\text { growth }\end{array}$ \\
\hline 2. & Expandability & Very Limited & Very Limited & $\begin{array}{l}\text { High. Higher loads } \\
\text { can be accepted } \\
\text { with extra media } \\
\text { Filling. }\end{array}$ \\
\hline 3. & $\begin{array}{l}\text { Area required for } \\
\text { STP, in hectares }\end{array}$ & 3.825 & 2.925 & 0.5575 \\
\hline 4. & $\begin{array}{l}\text { Total land cost, } \\
\text { Rs. Lacs }\end{array}$ & 45.9 & 35.1 & 6.69 \\
\hline 5. & $\begin{array}{c}\text { Total power } \\
\text { cost/annum, Rs. } \\
\text { Lacs }\end{array}$ & 1.77 & 47.56 & 36.5 \\
\hline 6. & $\begin{array}{c}\text { Maintenance cost } \\
\text { per annum, Rs. } \\
\text { Lacs } \\
\text { (Including } \\
\text { manpower, power, } \\
\text { chemicals) }\end{array}$ & 72.47 & 156.03 & 47.71 \\
\hline 7. & $\begin{array}{c}\text { Capital Cost, Rs. } \\
\text { Lacs } \\
\end{array}$ & 600 & 922.5 & 585 \\
\hline 8. & Source of sewage & $\begin{array}{l}\text { Manimajra township, } \\
\text { Modern Housing } \\
\text { Complex,Shivalik } \\
\text { Enclave and Mauli } \\
\text { Jagran Colony }\end{array}$ & $\begin{array}{l}\text { Raipur Khurd, } \\
\text { Hallomajra, Behlana, } \\
\text { Makhnanmajra and } \\
\text { Daria village }\end{array}$ & $\begin{array}{c}\text { Sector } \\
20,21,43,44,47,48, \\
36,50,51,52,49,61,6 \\
2,64,80,81,83 \text { of } \\
\text { Chandigarh } \\
\text { city }\end{array}$ \\
\hline
\end{tabular}

\section{SELECTION OF SITES AND SAMPLING POINTS}

\section{Materials And Methodology}

Samples for analysis were collected from the three STP's mentioned above namely: Raipur Kalan STP, Raipur Khurd STP and "Diggian" Mohali STP. The major area from which samples were collected i.e the sampling points were: Inlet and Final Outlet of Raipur Kalan STP, Raipur Khurd STP and "Diggian” Mohali STP Samples were collected 3 times, one each, in month of FEBRUARY, MARCH and APRIL. During the duration of study.

PARAMETERS ANALYSED 
1. Physico-chemical parameters : The parameters analyzed in this study were $\mathrm{pH}, \mathrm{Temp}$ (Temperature), TSS (Total Suspended Solids), TDS (Total Dissolved Solids), Oil and Grease, chlorides and Chemical Oxygen Demand (COD).

2. Biological parameters: The biological parameters analyzed in present study included Biochemical Oxygen Demand (BOD)

3. Nutrient Load : The Nutrients analysed in this study were Nitrate-Nitrogen $\left(\mathrm{NO}_{3}-\mathrm{N}\right)$, Ammonical Nitrogen $\left(\mathrm{NH}_{3}-\mathrm{N}\right)$ and Phosphate $\left(\mathrm{PO}_{4}^{-}\right)$

Results

III. Results And Discussions

Average Characteristics Of Influent And Effluent of all the 3 STP's in the month of February, March and April

\begin{tabular}{|c|c|c|c|c|c|c|}
\hline \multirow[t]{2}{*}{ Parameters } & \multicolumn{2}{|c|}{$\begin{array}{l}\text { Raipur Kalan STP } \\
\text { (UASB Technology) }\end{array}$} & \multicolumn{2}{|c|}{$\begin{array}{l}\text { Raipur Khurd STP } \\
\text { (ASP Technology) }\end{array}$} & \multicolumn{2}{|c|}{$\begin{array}{c}\text { Mohali STP (MBBR } \\
\text { Technology) }\end{array}$} \\
\hline & Influent & Effluent & Influent & Effluent & Influent & Effluent \\
\hline pH & 7.5 & 8.2 & 7.7 & 8.3 & 7.5 & 8.0 \\
\hline Temp & 23.1 & 22.8 & 23.4 & 22.5 & 22.7 & 22.1 \\
\hline TSS & 139.6 & 32.3 & 182.3 & 89.6 & 157.0 & 33.6 \\
\hline TDS & 270.6 & 163.3 & 275.3 & 146.0 & 281.3 & 125.6 \\
\hline Oil and grease & 3.0 & 0.4 & 3.9 & 0.6 & 4.4 & 0.5 \\
\hline BOD $_{3,27^{\circ} \mathrm{C}}$ & 166.3 & 33.6 & 146.6 & 38.3 & 186.6 & 23.3 \\
\hline COD & 338.3 & 148.3 & 377.3 & 83.0 & 346.6 & 67.6 \\
\hline $\mathrm{Cl}^{-}$ & 180.6 & 66.0 & 125.3 & 70.0 & 166.6 & 139.3 \\
\hline $\mathrm{NO}_{3}-\mathrm{N}$ & 3.1 & 1.9 & 4.1 & 1.7 & 4.4 & 1.6 \\
\hline $\mathrm{NH}_{3}-\mathrm{N}$ & 25.9 & 32.4 & 27.7 & 31.8 & 19.6 & 21.9 \\
\hline $\mathrm{PO}_{4}^{-}$ & 15.3 & 4.8 & 17.5 & 5.0 & 18.1 & 2.1 \\
\hline
\end{tabular}

Average Temperature of Ghaggar river at the time of results calculated in FEBRUARY, MARCH and APRIL was $26.4^{\circ} \mathrm{C}$

Comparison of all the three STP's Effluent with Central Pollution Control Board (CPCB), General Standards for the Discharge of Environmental Pollutants according to The Environment (Protection) Rules, 1986 Schedule-VI Part -A: Effluents

\begin{tabular}{|c|c|c|c|c|}
\hline Parameter & $\begin{array}{c}\text { Raipur Kalan } \\
\text { STP } \\
\text { (UASB) } \\
\text { Technology } \\
\text { Average Effluent }\end{array}$ & $\begin{array}{l}\text { Raipur Khurd } \\
\text { STP } \\
\text { (ASP) Technology } \\
\text { Average Effluent }\end{array}$ & $\begin{array}{c}\text { Mohali STP } \\
\text { (MBBR) } \\
\text { Tecnology } \\
\text { Average Effluent }\end{array}$ & $\begin{array}{c}\text { Comparison Result } \\
\text { With CPCB } \\
\text { Effluent Discharge } \\
\text { Standards } \\
\text { into Inland Surface Water }\end{array}$ \\
\hline pH & 8.2 & 8.3 & 8.0 & $\begin{array}{l}\text { Lower than Permissible } \\
\text { Limit }\end{array}$ \\
\hline Temp & 22.8 & 22.5 & 22.1 & $\begin{array}{l}\text { Lower than Permissible } \\
\text { Limit }\end{array}$ \\
\hline TSS & 32.3 & 89.6 & 33.6 & $\begin{array}{l}\text { Lower than Permissible } \\
\text { Limit }\end{array}$ \\
\hline TDS & 163.3 & 146.0 & 125.6 & $\begin{array}{l}\text { Lower than Permissible } \\
\text { Limit }\end{array}$ \\
\hline Oil and Grease & 0.4 & 0.6 & 0.5 & $\begin{array}{l}\text { Lower than Permissible } \\
\text { Limit }\end{array}$ \\
\hline $\mathrm{BOD}_{3,27^{\circ} \mathrm{C}}$ & 33.6 & 38.3 & 23.3 & $\begin{array}{c}\text { Higher than Permissible } \\
\text { Limit for Raipur Kalan STP } \\
\text { and Raipur Khurd STP }\end{array}$ \\
\hline COD & 148.3 & 83.0 & 67.6 & $\begin{array}{l}\text { Lower than Permissible } \\
\text { Limit }\end{array}$ \\
\hline $\mathrm{Cl}^{-}$ & 66.0 & 70.0 & 139.3 & $\begin{array}{c}\text { Lower than Permissible } \\
\text { Limit }\end{array}$ \\
\hline $\mathrm{NO}_{3}-\mathrm{N}$ & 1.9 & 1.7 & 1.6 & $\begin{array}{l}\text { Lower than Permissible } \\
\text { Limit }\end{array}$ \\
\hline $\mathbf{N H}_{3}-\mathbf{N}$ & 32.3 & 31.8 & 21.9 & $\begin{array}{l}\text { Lower than Permissible } \\
\text { Limit }\end{array}$ \\
\hline
\end{tabular}


A Comparative Study Of Sewerage Treatment Plants With Different Technologies In The Vicinity

\begin{tabular}{|c|c|c|c|c|}
\hline $\mathrm{PO}_{4}^{-}$ & 4.8 & 5.0 & 2.1 & $\begin{array}{l}\text { Lower than Permissible } \\
\text { Limit for Raipur Kalan STP } \\
\text { and Mohali STP but Exactly } \\
\text { upto Permissible Limit for } \\
\text { Raipur Khurd STP }\end{array}$ \\
\hline
\end{tabular}

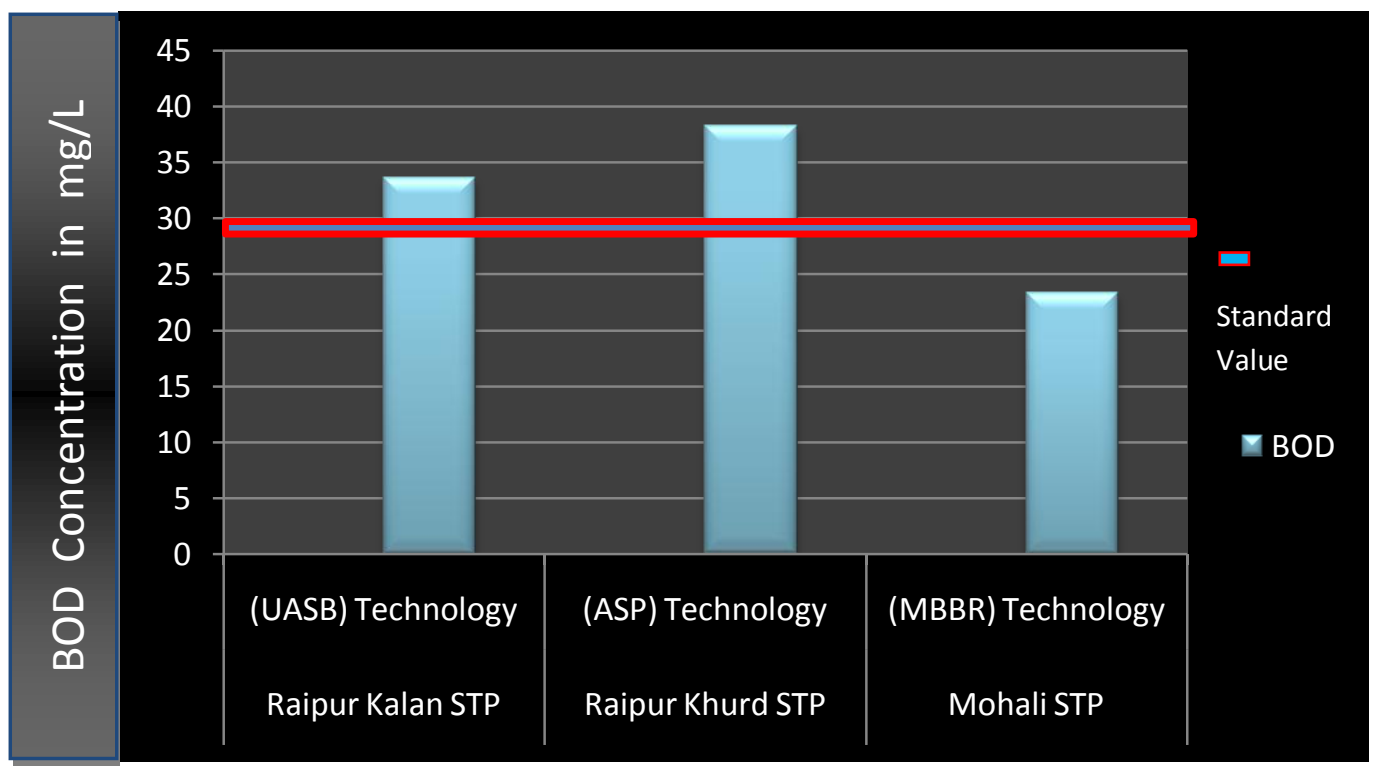

Graphical Representation of Parameter Exceeding CPCB Standard

Overall Performance or Removal/Reduction Efficiency of all the 3 STP's

\begin{tabular}{|c|c|c|c|}
\hline $\begin{array}{c}\text { Removal/Reduction } \\
\text { Efficiency }\end{array}$ & $\begin{array}{c}\text { Raipur Kalan } \\
\text { STP } \\
\text { (UASB) } \\
\text { Technology }\end{array}$ & $\begin{array}{c}\text { Raipur Khurd } \\
\text { STP } \\
\text { (ASP) } \\
\text { Technology }\end{array}$ & $\begin{array}{c}\text { Mohali STP } \\
\text { (MBBR) } \\
\text { Technology }\end{array}$ \\
\hline TSS & $76 \%$ & $51 \%$ & $78 \%$ \\
\hline TDS & $39 \%$ & $46 \%$ & $55 \%$ \\
\hline COD & $56 \%$ & $78 \%$ & $80 \%$ \\
\hline BOD $_{3,27}{ }^{\circ} \mathbf{C}$ & $79 \%$ & $73 \%$ & $88 \%$ \\
\hline
\end{tabular}

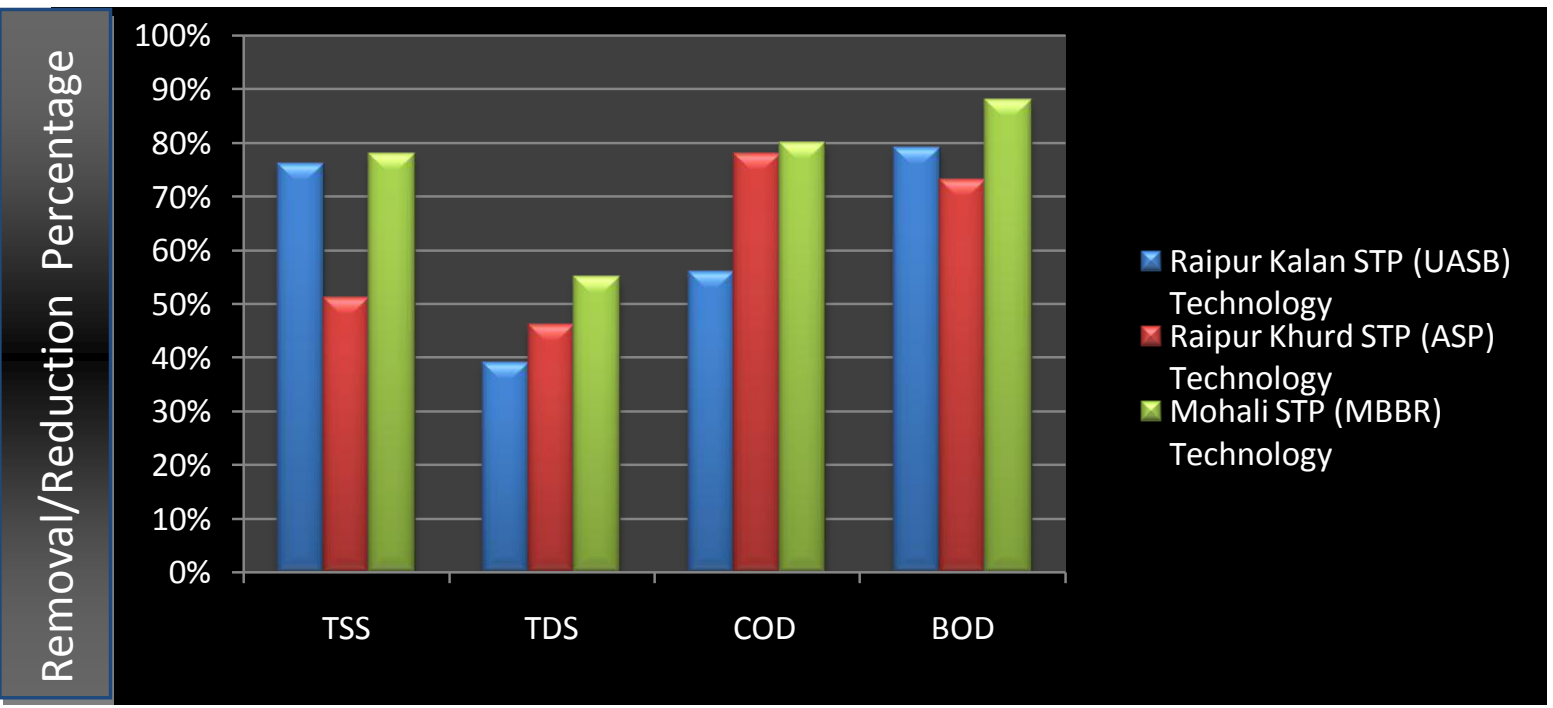

Graphical Representation of Overall Performance Or Removal/Reduction Efficiency of all the 3 STP's 
Since out of 30 MGD of STP, Mohali 10 MGD treated waste water is reused for Irrigation purpose in various gardens and lawns of Sector: 19, 20, 21, 29, 30, 33, 34, 36, 40, 42, 43, 44, 46, 47, 48, 51 and 52 of Chandigarh city therefore Average Effluent of this STP is compared with the CPCB Effluent Discharge Standards into Land for Irrigation.

\section{Comparison of Mohali STP, (MBBR) Technology, Average Effluent With the CPCB Effluent Discharge Standards into Land for Irrigation}

\begin{tabular}{|c|c|c|}
\hline Parameter & $\begin{array}{c}\text { Mohali STP } \\
\text { (MBBR) } \\
\text { Technology } \\
\text { Average Effluent }\end{array}$ & $\begin{array}{c}\text { Comparison Result With CPCB } \\
\text { Effluent Discharge Standards } \\
\text { into Land for Irrigation }\end{array}$ \\
\hline pH & 8.0 & Lower than Permissible Limit \\
\hline Temp & 22.1 & Lower than Permissible Limit \\
\hline TSS & 33.6 & - \\
\hline TDS & 125.6 & Lower than Permissible Limit \\
\hline Oil and Grease $_{\mathbf{B O D}_{\mathbf{3}, \mathbf{2 7}}{ }^{\circ} \mathbf{C}}$ & 0.5 & Lower than Permissible Limit \\
\hline $\mathbf{C O D}^{-}$ & 23.3 & \\
\hline $\mathbf{C O}^{-}-\mathbf{N}$ & 67.6 & - \\
\hline $\mathbf{N H}_{\mathbf{3}}-\mathbf{N}$ & 139.3 & - \\
\hline $\mathbf{P O}_{\mathbf{4}}^{-}$ & 1.6 & \\
\hline
\end{tabular}

\section{Discussions:}

pH:. During the course of the study it was recorded that $\mathrm{pH}$ varies from acidic to alkaline i.e 6.8-7.9, 6.9-8.4 and alkaline i.e 7.2-7.8 for Influent of STP Raipur Kalan, Raipur Khurd and Mohali respectively. Maximum $\mathrm{pH}$ value was recorded in the month of Feb, March and March for Influent of STP Raipur Kalan, Raipur Khurd and Mohali respectively. Average $\mathrm{pH}$ value of the Influent was recorded as 7.5, 7.7 and 7.5 for STP Raipur Kalan, Raipur Khurd and Mohali respectively indicating that the Influent was alkaline in nature for all the three STP's. Also during the course of the study it was recorded that $\mathrm{pH}$ varies from 7.7-8.6, 7.7-8.9 and 7.6-8.4 for Effluent of STP Raipur Kalan, Raipur Khurd and Mohali respectively which indicates that for all the above mentioned STP's the Effluent during the duration of study was alkaline in nature. Maximum $\mathrm{pH}$ value was recorded in the month of Feb, March and March for effluent of STP Raipur Kalan, Raipur Khurd and Mohali respectively. Average pH value of the Effluent was recorded as 8.2, 8.3 and 8.0 for STP Raipur Kalan, Raipur Khurd and Mohali respectively which clearly shows that the Effluent from above three STP's were alkaline in nature. Also Average $\mathrm{pH}$ value of the Effluent for all the three STP's were under Permissible Limit according to CPCB Effluent Discharge Standards into Inland Surface water. Since out of 30 MGD of STP, Mohali 10 MGD treated waste water is reused for Irrigation purpose in various gardens and lawns of of Chandigarh city, Average Effluent value of $\mathrm{pH}$ recorded for this STP was also under permissible limit according to CPCB Effluent Discharge Standards into Land for Irrigation.

Temperature (Temp): In the present study temperature varies from $18.4-26.3^{\circ} \mathrm{C}, 18.6-29.9^{\circ} \mathrm{C}$ and $18.3-26.1^{\circ} \mathrm{C}$ for Influent of STP Raipur Kalan, Raipur Khurd and Mohali respectively. Maximum temperature value of influent was recorded in the month of April for all the three STP's. Average temperature was recorded as $23.1^{\circ} \mathrm{C}, 23.4^{\circ} \mathrm{C}$ and $22.7^{\circ} \mathrm{C}$ for Influent of STP Raipur Kalan, Raipur Khurd and Mohali respectively. Not much variation was found in temperature of Influent for all the three STP's. Also it was recorded that temperature varies from $18.1-27.4^{\circ} \mathrm{C}, 18.0-27.7^{\circ} \mathrm{C}$ and $17.7-26.5^{\circ} \mathrm{C}$ for Effluent of STP Raipur Kalan, Raipur Khurd and Mohali respectively. Maximum temperature value of Effluent was recorded in the month of April for all the three STP's. Average temperature was recorded as $22.8^{\circ} \mathrm{C}, 22.5^{\circ} \mathrm{C}$ and $22.1^{\circ} \mathrm{C}$ for Effluent of STP Raipur Kalan, Raipur Khurd and Mohali respectively. Not much variation was found in temperature of Effluent for all the three STP's. Also Average temperature value of the Effluent for all the three STP's were under Permissible Limit according to CPCB Effluent Discharge Standards into Inland Surface water.

Total Suspended Solids (TSS) and Total dissolved Solids (TDS):

TSS: In the present study it was recorded that TSS varies from $126-159 \mathrm{mg} / \mathrm{L}, 141-238 \mathrm{mg} / \mathrm{L}$ and $149-$ $172 \mathrm{mg} / \mathrm{L}$ for the Influent of STP Raipur Kalan, Raipur Khurd and Mohali respectively. Maximum TSS value was recorded in the month of Feb, March and Feb for Influent of STP Raipur Kalan, Raipur Khurd and Mohali respectively. Average TSS value of the Influent was recorded as $139.6 \mathrm{mg} / \mathrm{L}, 182.3 \mathrm{mg} / \mathrm{L}$ and $157.0 \mathrm{mg} / \mathrm{L}$ for 
STP Raipur Kalan, Raipur Khurd and Mohali respectively. Average TSS value for the Influent of all the three STP's indicated much variation among the three STP's in terms of TSS value for the Influent, which is attributed to large difference in the organic and inorganic loading of solids with liquid content in all the three STP's. In the present study it was recorded that TSS varies from $29-38 \mathrm{mg} / \mathrm{L}, 51-155 \mathrm{mg} / \mathrm{L}$ and $30-39 \mathrm{mg} / \mathrm{L}$ for the Effluent of STP Raipur Kalan, Raipur Khurd and Mohali respectively. Maximum TSS value was recorded in the month of Feb, March and March for Effluent of STP Raipur Kalan, Raipur Khurd and Mohali respectively. Average TSS value of the Effluent was recorded as $32.3 \mathrm{mg} / \mathrm{L}, 89.6 \mathrm{mg} / \mathrm{L}$ and $157.0 \mathrm{mg} / \mathrm{L}$ for STP Raipur Kalan, Raipur Khurd and Mohali respectively. Average TSS value for the Effluent of all the three STP's indicated much variation among the three STP's in terms of TSS value for the Effluent, which is again attributed to large difference in the organic and inorganic loading of solids with liquid content in all the three STP's. Also Average TSS value of the Effluent for all the three STP's were under Permissible Limit according to CPCB Effluent Discharge Standards into Inland Surface water. Since out of 30 MGD of STP, Mohali 10 MGD treated waste water is reused for Irrigation purpose in various gardens and Chandigarh city, Average Effluent value of TSS value recorded for this STP was also under permissible limit according to CPCB Effluent Discharge Standards into Land for Irrigation.

TDS: In the present study it was recorded that TDS varies from $237-292 \mathrm{mg} / \mathrm{L}, 229-312 \mathrm{mg} / \mathrm{L}$ and $254-$ $299 \mathrm{mg} / \mathrm{L}$ for the Influent of STP Raipur Kalan, Raipur Khurd and Mohali respectively. Maximum TDS value of Influent was recorded in the month of March for all the three STP's. Average TDS value of the Influent was recorded as $270.6 \mathrm{mg} / \mathrm{L}, 275.3 \mathrm{mg} / \mathrm{L}$ and $281.3 \mathrm{mg} / \mathrm{L}$ for STP Raipur Kalan, Raipur Khurd and Mohali respectively. Average TDS value for the Influent of all the three STP's indicated not much variation among the three STP's in terms of TDS value for the Influent, which is attributed to less difference in the organic and inorganic loading of solids with liquid content in all the three STP's. In the present study it was recorded that TDS varies from $157-173 \mathrm{mg} / \mathrm{L}, 122-169 \mathrm{mg} / \mathrm{L}$ and $106-140 \mathrm{mg} / \mathrm{L}$ for the Effluent of STP Raipur Kalan, Raipur Khurd and Mohali respectively. Maximum TDS value was recorded in the month of March, Feb and March for Effluent of STP Raipur Kalan, Raipur Khurd and Mohali respectively. Average TDS value of the Effluent was recorded as $163.3 \mathrm{mg} / \mathrm{L}, 146.0 \mathrm{mg} / \mathrm{L}$ and $125.6 \mathrm{mg} / \mathrm{L}$ for STP Raipur Kalan, Raipur Khurd and Mohali respectively. Average TDS value for the Effluent of all the three STP's indicated much variation among the three STP's in terms of TDS value for the Effluent, which is again attributed to large difference in the organic and inorganic loading of solids with liquid content in all the three STP's. Also Average TDS value of the Effluent for all the three STP's were under Permissible Limit according to CPCB Effluent Discharge Standards into Inland Surface water.

Oil and grease: In the present investigation it was recorded that Oil and Grease varies from 2.4-3.7 mg/L, 3.6$4.5 \mathrm{mg} / \mathrm{L}$ and 3.3-5.2 mg/L for the Influent of STP Raipur Kalan, Raipur Khurd and Mohali respectively. Also was recorded that Oil and Grease varies from $0.2-0.6 \mathrm{mg} / \mathrm{L}, 0.3-0.9 \mathrm{mg} / \mathrm{L}$ and $0.2-0.9 \mathrm{mg} / \mathrm{L}$ for the Effluent of STP Raipur Kalan, Raipur Khurd and Mohali respectively. Not much variation was observed in Influent and Effluent value of Oil and Grease for all the three STP's which shows that the discharge from the various sources of Oil and Grease contain less amount of oily and greasy material during the duration of study. Also Average Oil and Grease value of the Effluent for all the three STP's were under Permissible Limit according to CPCB Effluent Discharge Standards into Inland Surface water. Since out of 30 MGD of STP, Mohali 10 MGD treated waste water is reused for Irrigation purpose in various gardens and lawns of Chandigarh city, Average Effluent value of Oil and Grease recorded for this STP was also under permissible limit according to CPCB Effluent Discharge Standards into Land for Irrigation.

Biochemical Oxygen Demand (BOD): During the study it was recorded that BOD varies from 154-169 mg/L, 140-151 mg/L and 184-189 mg/L for the Influent of STP Raipur Kalan, Raipur Khurd and Mohali respectively. Maximum BOD value of Influent was recorded in the month of April, March and April for Influent of STP Raipur Kalan, Raipur Khurd and Mohali respectively. The highest value of BOD for Influent of the above three STP's noticed clearly indicates that this highest value is attributed to heavy organic and inorganic loading with less amount of water in the above mentioned months. Average BOD was recorded as $166.3 \mathrm{mg} / \mathrm{L}, 146.63 \mathrm{mg} / \mathrm{L}$ and $186.63 \mathrm{mg} / \mathrm{L}$ for the Influent of STP Raipur Kalan, Raipur Khurd and Mohali respectively, high average value of BOD for all the three STP's indicates the degree of pollution of Influent in each STP. Also DO was very less at inlet for all three STP's which is further stimulated by oxidation of sewage ammonia to nitrates, septic condition and heavy organic loadings, therefore high BOD value are obtained at inlet in all the three STP's . Out of all the three STP's mentioned above the average BOD value was maximum in Mohali STP. BOD value for Effluent was in the range of 32-35 mg/L, 31-47 mg/L and 17-27 mg/L of STP Raipur Kalan, Raipur Khurd and Mohali respectively. Average BOD value for Effluent recorded was $33.6 \mathrm{mg} / \mathrm{L}, 38.3 \mathrm{mg} / \mathrm{L}$ and 23.3 $\mathrm{mg} / \mathrm{L}$ of STP Raipur Kalan, Raipur Khurd and Mohali respectively. It was observed that average BOD value for 
Effluent of STP Raipur Kalan and Raipur Khurd was not under permissible limit according to CPCB Effluent Discharge Standards into Inland Surface water. But average BOD value for Effluent of STP Mohali was under permissible limit according to CPCB Effluent Discharge Standards into Inland Surface water.

Since out of 30 MGD of STP, Mohali 10 MGD treated waste water is reused for Irrigation purpose in various gardens and lawns of Sector: 19, 20, 21, 29, 30, 33, 34, 36, 40, 42, 43, 44, 46, 47, 48, 51 and 52 of Chandigarh city, Average Effluent value of BOD recorded for this STP was also under permissible limit according to CPCB Effluent Discharge Standards into Land for Irrigation.

Chemical Oxygen Demand (COD): In the present study COD value varies from 299-367 mg/L, 358-395 mg/L and 312-371 mg/L for the Influent of STP Raipur Kalan, Raipur Khurd and Mohali respectively. Maximum COD value of Influent was recorded in the month of Feb for Influent of all the three STP's. Highest value of $\mathrm{COD}$ in the month of Feb was due to the heavy organic loading with less amount of water. Average Influent value of COD recorded was $338.3 \mathrm{mg} / \mathrm{L}, 377.3 \mathrm{mg} / \mathrm{L}$ and $346.6 \mathrm{mg} / \mathrm{L}$ for the Influent of STP Raipur Kalan, Raipur Khurd and Mohali respectively. Not much variation was found in COD value for the Influent of STP Raipur Kalan, Raipur Khurd and Mohali. COD value recorded in the range of 105-196 mg/L, 72-99 mg/L and 56-84 mg/L for the Effluent of STP Raipur Kalan, Raipur Khurd and Mohali respectively. Average COD value was recorded as $148.3 \mathrm{mg} / \mathrm{L}, 83 \mathrm{mg} / \mathrm{L}$ and $67.6 \mathrm{mg} / \mathrm{L}$ for the Effluent of STP Raipur Kalan, Raipur Khurd and Mohali respectively. It was observed that average COD value for Effluent of STP Raipur Kalan, Raipur Khurd and Mohali was under permissible limit according to CPCB Effluent Discharge Standards into Inland Surface water.

\section{Chloride (Cl}

In the present study $\mathrm{Cl}^{-}$value varies from $169-192 \mathrm{mg} / \mathrm{L}, 11-147 \mathrm{mg} / \mathrm{L}$ and $158-174 \mathrm{mg} / \mathrm{L}$ for the Influent of STP Raipur Kalan, Raipur Khurd and Mohali respectively. Average Influent value of $\mathrm{Cl}^{-}$recorded was $180.6 \mathrm{mg} / \mathrm{L}, 125.3 \mathrm{mg} / \mathrm{L}$ and $166.6 \mathrm{mg} / \mathrm{L}$ for the Influent of STP Raipur Kalan, Raipur Khurd and Mohali respectively. Not much variation was found in $\mathrm{Cl}^{-}$value for the Influent of STP Raipur Kalan, Raipur Khurd and Mohali which indicates that there is no presence of industrial waste or infiltration of sea water which generally attributes to the strength of sewage. $\mathrm{Cl}^{-}$value recorded in the range of $53-88 \mathrm{mg} / \mathrm{L}, 33-98 \mathrm{mg} / \mathrm{L}$ and $106-199$ $\mathrm{mg} / \mathrm{L}$ for the Effluent of STP Raipur Kalan, Raipur Khurd and Mohali respectively. Average $\mathrm{Cl}^{-}$value was recorded as $66.0 \mathrm{mg} / \mathrm{L}, 70.0 \mathrm{mg} / \mathrm{L}$ and $139.3 \mathrm{mg} / \mathrm{L}$ for the Effluent of STP Raipur Kalan, Raipur Khurd and Mohali respectively. Average $\mathrm{Cl}^{-}$value of Effluent for the three STP's indicates much variation among the three with respect to the chloride content. It was observed that average $\mathrm{Cl}^{-}$value for Effluent of STP Raipur Kalan, Raipur Khurd and Mohali was under permissible limit according to CPCB Effluent Discharge Standards into Inland Surface water.

\section{Nutrient Load:}

Ammonical nitrogen $\left(\mathbf{N H}_{3}-\mathbf{N}\right): \mathrm{NH}_{3}-\mathrm{N}$ in the present study varies from $19.5-29.7 \mathrm{mg} / \mathrm{L}, 23.2-34.8 \mathrm{mg} / \mathrm{L}$ and 17.5-21.6 mg/L for the Influent of STP Raipur Kalan, Raipur Khurd and Mohali respectively. Average Influent value of $\mathrm{NH}_{3}-\mathrm{N}$ recorded was $25.9 \mathrm{mg} / \mathrm{L}, 27.7 \mathrm{mg} / \mathrm{L}$ and $19.6 \mathrm{mg} / \mathrm{L}$ for the Influent of STP Raipur Kalan, Raipur Khurd and Mohali respectively indicating little bit variation in $\mathrm{NH}_{3}-\mathrm{N}$ Influent for the above three STP's. Effluent value for $\mathrm{NH}_{3}-\mathrm{N}$ was recorded in the range of $28.8-38.3 \mathrm{mg} / \mathrm{L}, 28.1-3.8 \mathrm{mg} / \mathrm{L}$ and 17.6-24.5 $\mathrm{mg} / \mathrm{L}$ for STP Raipur Kalan, Raipur Khurd and Mohali respectively. Average Effluent value for $\mathrm{NH}_{3}-\mathrm{N}$ recorded was $25.9 \mathrm{mg} / \mathrm{L}, 27.7 \mathrm{mg} / \mathrm{L}$ and $19.6 \mathrm{mg} / \mathrm{L}$ of STP Raipur Kalan, Raipur Khurd and Mohali respectively. Effluent value of increases than the influent value in all the months during the duration of study of STP Raipur Kalan, indicating that nitrogenous organic matter is decomposed properly and and $\mathrm{NH}_{3}$ is evolved as an end product. Moreover Average Effluent value for $\mathrm{NH}_{3}-\mathrm{N}$ of all the three STP's was under permissible limit according to CPCB Effluent Discharge Standards into Inland Surface water.

\section{Nitrate nitrogen $\left(\mathrm{NO}_{3}-\mathrm{N}\right)$}

$\mathrm{NO}_{3}-\mathrm{N}$ value was recorded in the range of 1.7-4.7 mg/L, 2.4-5.9 mg/L and 3.3-5.2 mg/L for the Influent of STP Raipur Kalan, Raipur Khurd and Mohali respectively. Average Influent value of $\mathrm{NO}_{3}-\mathrm{N}$ recorded was 3.1 $\mathrm{mg} / \mathrm{L}, 4.1 \mathrm{mg} / \mathrm{L}$ and $4.4 \mathrm{mg} / \mathrm{L}$ for the Influent of STP Raipur Kalan, Raipur Khurd and Mohali respectively indicating that $\mathrm{NO}_{3}-\mathrm{N}$ content in the inlet of all the three STP's were almost the same as same amount of nitrogenous organic matter entered in all the above three STP's. In the present study it was recorded that Effluent value for $\mathrm{NO}_{3}-\mathrm{N}$ varies from $1.3-3.2 \mathrm{mg} / \mathrm{L}, 1.4-2.3 \mathrm{mg} / \mathrm{L}$ and $1.2-2.4 \mathrm{mg} / \mathrm{L}$ for the Effluent of STP Raipur Kalan, Raipur Khurd and Mohali respectively. Average Effluent value for $\mathrm{NO}_{3}-\mathrm{N}$ recorded was 1.9 $\mathrm{mg} / \mathrm{L}, 1.7 \mathrm{mg} / \mathrm{L}$ and $1.6 \mathrm{mg} / \mathrm{L}$ of STP Raipur Kalan, Raipur Khurd and Mohali respectively indicating that $\mathrm{NO}_{3}$ $-\mathrm{N}$ content in the outlet of all the three STP's were almost the same. Moreover Average Effluent value for $\mathrm{NO}_{3}$ 
$-\mathrm{N}$ of all the three STP's was under permissible limit according to CPCB Effluent Discharge Standards into Inland Surface water.

Phosphate $\left(\mathbf{P O}_{4}{ }^{-}\right) \quad \mathrm{PO}_{4}{ }^{-}$value varies from 11.6-14.9 mg/L, 15.2-20.2 mg/L and 13.5-24.8 mg/L for the Influent of STP Raipur Kalan, Raipur Khurd and Mohali respectively. Average Influent value of $\mathrm{PO}_{4}^{-}$recorded was 15.3 $\mathrm{mg} / \mathrm{L}, 17.5 \mathrm{mg} / \mathrm{L}$ and $18.1 \mathrm{mg} / \mathrm{L}$ of STP Raipur Kalan, Raipur Khurd and Mohali respectively indicating that phosphates content entering the inlet of all the above three STP's was near about the same. In the present study $\mathrm{PO}_{4}{ }^{-}$value varies from 3.8-5.5 mg/L, 3.9-7.8 mg/L and 1.4-2.9 mg/L for the Effluent of STP Raipur Kalan, Raipur Khurd and Mohali respectively. Average Effluent value of $\mathrm{PO}_{4}{ }^{-}$recorded was $15.3 \mathrm{mg} / \mathrm{L}, 17.5 \mathrm{mg} / \mathrm{L}$ and $18.1 \mathrm{mg} / \mathrm{L}$ of STP Raipur Kalan, Raipur Khurd and Mohali respectively. Average Effluent value of $\mathrm{PO}_{4}{ }^{-}$ recorded was $4.8 \mathrm{mg} / \mathrm{L}, 5.0 \mathrm{mg} / \mathrm{L}$ and $2.1 \mathrm{mg} / \mathrm{L}$ of STP Raipur Kalan, Raipur Khurd and Mohali respectively. Moreover Average Effluent value for $\mathrm{PO}_{4}^{-}$of STP Raipur Kalan and Mohali was under permissible limit according to CPCB Effluent Discharge Standards into Inland Surface water, but Average Effluent value for $\mathrm{PO}_{4}{ }^{-}$ of STP Raipur Khurd was exactly upto permissible limit according to CPCB Effluent Discharge Standards into Inland Surface water.

Determination of all the above the three nutrients were important also from the point of view that there increased concentration in effluent may cause eutrophication of river Ghaghar, in which the effluent of all the above three STP's is disposed of. Hence proper concentration of all the above three nutrients should be maintained before discharging the sewage effluent into the water body.

\section{Conclusions And Recommendation}

CONCLUSIONS: From the study conducted for the comparison of 3 STP's in the vicinity of Chandigarh city following conclusions are made:

Physico-Chemical and Biological Parameters evaluated for STP Mohali was under permissible limit according to CPCB Effluent Discharge Standards into Inland Surface Water during the course of study. Since out of 30 MGD of STP, Mohali 10 MGD treated waste water is reused for Irrigation purpose in various gardens and lawns of Sector: 19, 20, 21, 29, 30, 33, 34, 36, 40, 42, 43, 44, 46, 47, 48, 51 and 52 of Chandigarh city therefore after evaluating various Physico-Chemical and Biological Parameters for this STP it was concluded that all the parameters evaluated were under permissible limit according to CPCB Effluent Discharge Standards into Land for Irrigation during the course of study. Hence Effluent from this STP is safer for agricultural use. BOD value of the Effluent of STP Raipur Kalan and Raipur Khurd was not under permissible limit during the course of study and Average Phosphate value of Raipur Khurd was exactly upto permissible limit during the duration of study according to Central Pollution Control Board (CPCB) General Standards for the Discharge of Environmental Pollutants Part -A: Effluents, into Inland Surface Water according to The Environment (Protection) Rules, 1986 Schedule-VI. Also it was revealed from the performance study that efficiency of the three STP's mentioned above was poor with respect to removal of TDS (Total Dissolved Solids) in contrast to the removal /reduction efficiency in other parameters like TSS (Total Suspended Solids), BOD (Biochemical Oxygen Demand) and COD (Chemical Oxygen Demand). The order of removal /reduction efficiency was 1.TDS(39\%) 2.COD(56\%) 3.TSS(76\%) 4.BOD(79\%), 1.TDS(46\%) 2.TSS(51\%) 3.BOD(73\%) 4.COD(78\%) and 1.TDS(55\%) 2.COD(75\%) 3.TSS(78\%) 4.BOD(88\%) respectively in Raipur Kalan STP, Raipur Khurd STP and "Diggian" Mohali STP. In comparison with each other, out of the three STP's, "Diggian" STP Located at Mohali showed better results for the effluent, its removal /reduction efficiency for BOD is $88 \%$ and is highest among Raipur Kalan STP and Raipur Khurd STP which is 79\% and 73\% respectively. The greater removal /reduction efficiency for STP Mohali is attributed to the chemical treatment employed at this STP in the form of Tertiary Treatment of sewage. From the evaluation it is further concluded that Mohali STP based upon MBBR technology have more stable results than Raipur Kalan STP, based upon UASB technology and Raipur Khurd STP, based upon ASP technology. The order of overall performance for the technologies studied in different STP's are: 1.MBBR 2.UASB 3.ASP which proves that MBBR technology is ahead to UASB and ASP technology in the treatment of sewage.

RECOMMENDATION: MBBR technology is recommended over ASP and UASB technology for treatment of Sewage.

\section{References}

[1]. APHA -AWWA-WPCF,2005.Standard Methods for Examination of Water and Wastewater, $21^{\text {st }}$ edition. American Public Health Association, Washington, DC,USA.

[2]. Swayer, Mc Carty and Parkin.Chemistry for environmental engineering and science, fifth edition, Tata Mc Graw -Hill.

[3]. Water and wastewater testing (A laboratory manual), R.P Mathur.

[4]. Priyanka Jamwal, Atul K. Mittal and Jean-Marie Mouchel. Efficiency evaluation of sewage treatment plants with different technologies in Delhi (India), Environ Monit Assess (2009) 153:293-305 


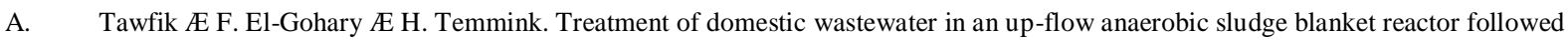
by moving bed biofilm reactor, Bioprocess Biosyst Eng (2010) 33:267-276

[5]. Dilip M. Ghaitidak \& Kunwar D. Yadav (2013). Characteristics and treatment of greywater-a review, Environ Sci Pollut Res DOI 10.1007/s11356-013-1533-0

[6]. Hospido A, Moreira MA, Feijoo G(2007): A Comparison of Municipal Wastewater TreatmentPlants for Big Centres of Population in Galicia (Spain). Int J LCA13 (1) 57-64

[7]. Ravi Kumar, P., Liza Britta Pinto and Somashekar, R.k . Assessment of the efficiency of sewage treatment plants: A comparative study between Nagasandra and Mailasandra sewage treatment plant, Kathmandu University Journal of Science,Engineering and Technology, Vol.6,No. II, Nov, 2010,pp 115-125.

[8]. M. Molinos-Senante, M. Garrido-Baserba , R. Reif , F. Hernández-Sancho and M. Poch. Assessment of wastewater treatment plant design for small communities:Environmental and economic aspects, Science of the Total Environment 427-428 (2012) 11-18

[9]. Kadiya Calderón, Jaime Martín-Pascual, José Manuel Poyatos , Belén Rodelas , Alejandro González-Martínez and Jesús González-López. Comparative analysis of the bacterial diversity in a lab-scale moving bed biofilm reactor (MBBR) applied to treat urban wastewater under differentoperational conditions, Bioresource Technology 121 (2012) 119-126

[10]. D. Pokhrel, T. Viraraghavan. Treatment of pulp and paper mill wastewater-a review, Science of the Total Environment 333 (2004) $37-58$

[11]. Madan Tandukara, A. Ohashib and H. Harada.Performance comparison of a pilot-scale UASB and DHS system and activated sludge process for the treatment of municipal wastewater, WAT ER RE S E ARCH 41 (2007) 2697 - 2705 Pradip P. Kalbar, Subhankar Karmakar, Shyam R. Asolekar. Technology assessment for wastewater treatment using multiple-attribute decisionmaking, Technology in Society 34 (2012) 295-302

[12]. Sheng Chen, Dezhi Sun, and Jong-Shik Chung. Treatment of pesticide wastewater by moving-bed biofilm reactor combined with Fenton-coagulation pretreatment, Journal of Hazardous Materials 144 (2007) 577-584

[13]. Ravichandran.M and Joshua Amarnath.D. Performance Evaluation of Moving Bed Bio-Film Reactor Technology for Treatment of Domestic Waste Water in Industrial Area at MEPZ (Madras Exports Processing Zone), Tambaram, Chennai, India, Elixir Pollution 53 (2012) $11741-11744$

[14]. I garashi, T., watanbe, Y, asano, T. and tambo, N. the moving bed biofilm reactor, Water Environmental Engineering and Reuse of Water, Hokkaido Press 1999,p. 250-305

[15]. Colmenarejo, M. F., Rubio, A., Sanchez, E., Vicente, J., Gracia,M. G., \& Bojra, R. (2006). Evaluaton of municipal wastewater treatment plants with different technologies at

[16]. Las-Rozas, Madrid (Spain). Journal of Environmental Management, 81, 399-404.

[17]. Metcalf and Eddy Inc., (2003), “Wastewater Engineering- Treatment, Disposal and Reuse”, 4 ${ }^{\text {th }}$ Edition, Tata McGraw Hill Publishinh Co. Ltd., New Delhi.

[18]. S.K Garg. Sewage Disposal and Air Pollution Engineering, Environmental Engineering (Vol.II)

[19]. Operation and Manitenance Manual for Sewage Treatment Plant, Municipal Corporation, Chandigarh. 